\title{
THE USE OF HAEMODIALYSIS IN ACUTE RENAL FAILURE AND OVERHYDRATION IN CHILDREN
}

\author{
BY \\ J. G. WALKER, M. GARSENSTEIN, BRENDA HIGGS, T. R. LAWSON and S. SHALDON \\ From the Department of Medicine, Royal Free Hospital, London
}

(RECEIVED FOR PUBLICATION AUgUST 2, 1962)

In spite of increasing interest in the use of haemodialysis, there have been few reports of its use in infancy and childhood (Mateer, Greenman and Danowski, 1955; Carter, Aoyama, Mercer and Kolff, 1957; Keleman and Kolff, 1959; Breakey, Woodruff and Reus, 1961).

We present here our experience of this problem in three children who were suffering from acute renal failure with signs of overhydration.

\section{Material and Methods}

The clinical details of the patients are listed in the Table. The Kolff disposable twin-coil kidney (Kolff and Watschinger, 1956) was used for all haemodialyses. In the older children (Cases 2 and 3) both coils of the kidney were used in the usual manner. However, in the 15-month-old infant (Case 1) only one coil was used and the priming volume was reduced to $500 \mathrm{ml}$. blood (Carter et al., 1957).

Percutaneous catheterization of femoral artery and vein (Shaldon, Chiandussi and Higgs, 1961) was performed on all patients. Bilateral femoral arterial and venous catheters were used in one patient (Case 3 ) and permitted flow rates of up to $500 \mathrm{ml}$. per minute. Dialysis catheters made from Odman-Ledin plastic yellow tubing (external diameter $3.0 \mathrm{~mm}$., internal diameter $1.6 \mathrm{~mm}$.) with added side ports and internal diameter at the tip $0.91 \mathrm{~mm}$. (Shaldon et al., 1961) were used in the older children. In the 15-month-old infant polyethylene (Clay Adams PE 160) catheters (external diameter $1.58 \mathrm{~mm}$., internal diameter $1.13 \mathrm{~mm}$., internal diameter at tip $0.91 \mathrm{~mm}$.) were introduced on four separate occasions into the femoral artery and vein without complication (Fig. 1).

Regional heparinization was used in all dialyses. The technique consisted of twin infusions of heparin and hexadimethrine introduced via a 'Sigma' constant infusion pump. The concentration of heparin used was 150 units per $\mathrm{ml}$. and of hexadimethrine $1.6 \mathrm{mg}$. per $\mathrm{ml}$., and both were infused at $1 \mathrm{ml}$. per minute. Efficiency of the regional heparinization circuit was checked by half-hourly clotting times of whole-blood. Blood from the dialysis circuit was kept at the approximate clotting time of 20-30 minutes, while the patient's clotting time rarely increased by more than one to two minutes over the control.

\section{Case Reports}

Case 1. A previously healthy 15 -month-old mala infant developed anuria following a severe attack of diarrhoea and vomiting. On arrival he was comatose with marked hyperventilation. He had had several bouts of convulsions and was clinically overhydrated with a blood pressure of $190 / 90 \mathrm{~mm}$. $\mathrm{Hg}$. In addition he was passing frequent melaena stools.

Investigations on admission revealed blood urea $400 \mathrm{mg}$. $/ 100 \mathrm{ml}$., serum potassium $6.0 \mathrm{mEq} / \mathrm{l}$., serum sodium $156 \mathrm{mEq} / \mathrm{l}$, serum chloride $107 \mathrm{mEq} / \mathrm{l}$, and serum bicarbonate $8 \mathrm{mEq} / \mathrm{l}$. Serum creatinine 10.9 mg./100 ml., serum uric acid $23.6 \mathrm{mg} . / 100 \mathrm{ml}$., serum calcium $9.6 \mathrm{mg} . / 100 \mathrm{ml}$., and serum inorganic phosphate $7.5 \mathrm{mg} . / 100 \mathrm{ml}$. Arterial $p \mathrm{H} \mathrm{7.08} ; \mathrm{PCO}_{2} 21 \mathrm{~mm}$. Hg. Cerebrospinal fluid investigations revealed the following: $p \mathrm{H} \mathrm{7.08;} \mathrm{bicarbonate} 6 \mathrm{mEq} / \mathrm{l}$; $\mathrm{PCO}_{2} 20 \mathrm{~mm}$. $\mathrm{Hg}$; protein $100 \mathrm{mg} . / 100 \mathrm{ml}$.; glucose $270 \mathrm{mg} . / 100 \mathrm{ml}$., and pressure $30 \mathrm{~mm}$. $\mathrm{Hg}$; microscopy of the cerebrospinal

TABLE

CLINICAL DATA AND TREATMENT OF THREE CHILDREN WITH ACUTE RENAL FAILURE

\begin{tabular}{|c|c|c|c|c|c|c|}
\hline Case No. & Age & Sex & Diagnosis & $\begin{array}{c}\text { Duration of Oliguria } \\
\text { (days) }\end{array}$ & No. of Dialyses & Result \\
\hline 1 & $15 \mathrm{mths}$ & $\mathbf{M}$ & Acute renal cortical necrosis & 22 & 4 & Survived \\
\hline 2 & $11 \mathrm{yrs}$ & $\mathbf{F}$ & Acute glomerulonephritis & 5 & 1 & Died \\
\hline 3 & 15 yrs & $\mathbf{M}$ & $\begin{array}{l}\text { Ethylene glycol poisoning with } \\
\text { acute renal failure }\end{array}$ & 14 & 5 & Survived \\
\hline
\end{tabular}




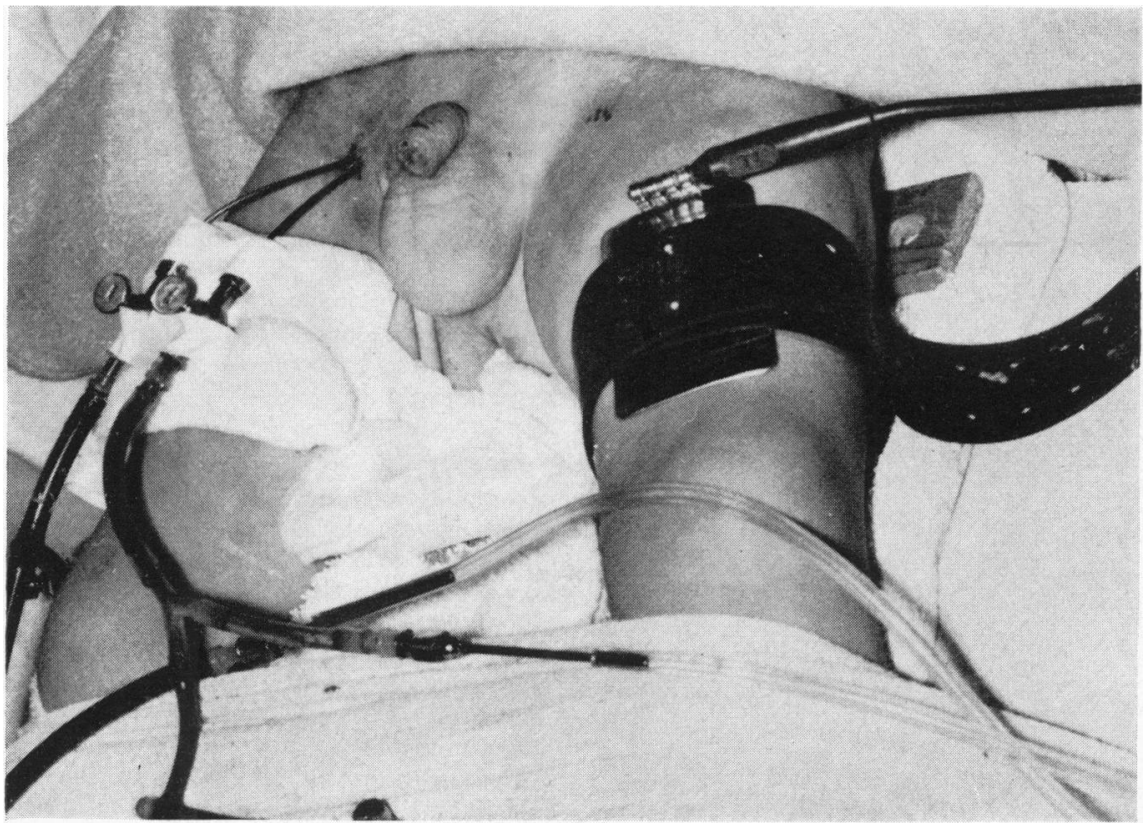

FIG. 1.-Case 1: the polyethylene catheters in place during dialysis.

fluid showed a normal cell count with no red cells present. Haemoglobin 3.6 g. $/ 100 \mathrm{ml}$, total white cell count 19,600 per c.mm. (polymorphonuclear leucocytes $80 \%$ ).

In view of the severe uraemia and overhydration an emergency haemodialysis was commenced. This was performed for three hours at a flow rate of $75 \mathrm{ml} . / \mathrm{min}$.; $19 \mathrm{~g}$. of urea were removed and the blood urea was reduced to $110 \mathrm{mg} . / 100 \mathrm{ml}$. The serum sodium fell to $137 \mathrm{mEq} / \mathrm{l}$. and the patiert lost $1 \mathrm{lb}$. $(453 \mathrm{~g}$.) in weight (Fig. 2). The blood pressure fell to $120 / 70 \mathrm{~mm}$. $\mathrm{Hg}$. Following dialysis the conscious level slowly improved and 24 hours later the baby was fully awake. At the end of the dialysis the blood $\mathrm{pH}$ had risen to $7 \cdot 49$, but the C.S.F. $p \mathrm{H}$ was still only $7 \cdot 18$. However, 24 hours later the C.S.F. $p \mathrm{H}$ had risen to $7 \cdot 46$, and this coincided with the maximum improvement in conscious level. The oliguric period lasted for 22 days and was complicated by the presence of repeated gastro-intestinal bleeding that required almost daily blood transfusion. This complication was in part responsible for the rapid rise of the blood urea. Further dialyses were required on the eighth, fourteenth and nineteenth days of renal failure. Each one lasted two hours and the flow rate varied between 50 and $100 \mathrm{ml}$. per minute. During the diuretic phase the blood urea fell to $80 \mathrm{mg}$. $/ 100 \mathrm{ml}$. Percutaneous renal biopsy (Fig. 3) performed with a modified Menghini needle on the 62 nd day after the onset of renal failure showed a patchy cortical necrosis with healing of the tubules. Plain radiograph of the abdomen at this time failed to show calcification of the renal shadows.

The infant was discharged from hospital on the 88th
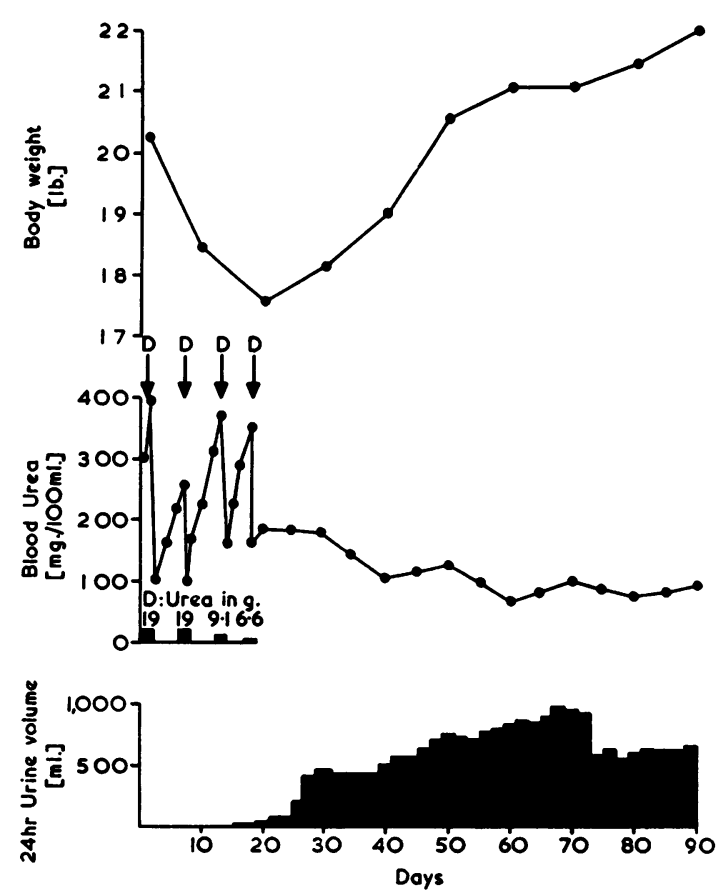

Fig. 2.-Case 1: clinical course and details of dialyses (D), with amounts of urea removed in grammes. 


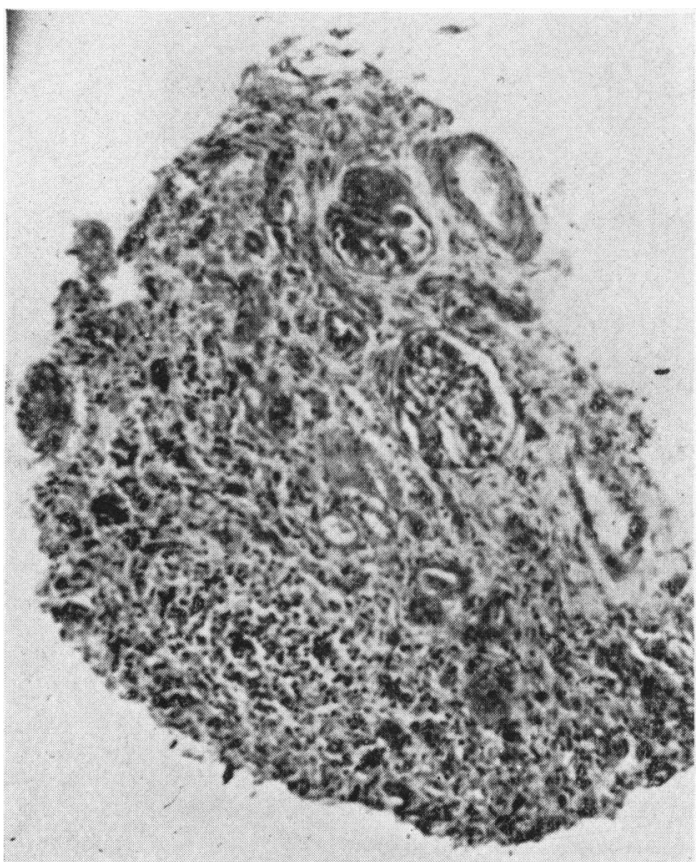

FIG. 3.-Case 1: renal biopsy on the 62 nd day of renal failure, showing extensive fibrosis and hyalinization of glomeruli with healing of tubules. $(\times 130$.

day, gaining weight and thriving, although the blood urea was still $80 \mathrm{mg}$. $/ 100 \mathrm{ml}$. with a serum creatinine of $1.5 \mathrm{mg} . / 100 \mathrm{ml}$. Six months later the infant was still healthy, although the blood urea remained raised at this level.

Comment. This infant developed acute renal failure following dehydration. The development of convulsions and hypertension was attributed to overhydration in the early anuric period and was corrected by removal of body water during haemodialysis. The acute renal failure was shown by renal biopsy to be due to patchy cortical necrosis.

Case 2. An 11-year-old girl became delirious and developed a skin rash 48 hours after the onset of a sore throat. During the next five days she became oliguric and subsequently anuric, and lapsed into coma. On admission she was overhydrated, deeply unconscious, hyperventilating and the blood pressure was 160/95 $\mathrm{mm}$. Hg. She passed several melaena stools shortly after admission.

Investigations revealed blood urea $350 \mathrm{mg} . / 100 \mathrm{ml}$., serum potassium $7.0 \mathrm{mEq} / 1$., serum sodium $128 \mathrm{mEq} / 1$., serum chloride $92 \mathrm{mEq} / \mathrm{l}$,, and serum bicarbonate $7 \mathrm{mEq} / \mathrm{l}$. The electrocardiogram showed high T-waves compatible with hyperkalaemia. Lumbar puncture yielded a normal fluid under normal pressure.

In view of the severe acidosis and high serum potassium she was dialysed immediately. Following a six-hour haemodialysis the blood urea was reduced to $90 \mathrm{mg}$./
$100 \mathrm{ml}$. and the serum bicarbonate rose to $18 \mathrm{mEq} / \mathrm{l}$. The blood pressure fell to $110 / 60 \mathrm{~mm}$. $\mathrm{Hg}$ and she lost $3 \mathrm{lb} .(1 \cdot 36 \mathrm{~kg}$.) in weight. However, her conscious level did not improve and she died 24 hours later. Autopsy revealed swollen kidneys, histologically showing presence of an acute glomerulonephritis. The heart was dilated and there was pulmonary oedema. The brain was swollen but histologically normal.

Comment. This patient had a severe fulminating acute glomerulonephritis and haemodialysis, and controlling the uraemia was unable to reverse the deep coma probably due to cerebral oedema in association with hypertension.

Case 3. A 15-year-old boy developed an acute encephalitis and anuria following the accidental ingestion of $50 \mathrm{ml}$. of ethylene glycol in an antifreeze mixture. On examination four days after ingestion of the poison he was unconscious, very irritable and responded to light stimuli with powerful movements of the limbs. The blood pressure was $160 / 90 \mathrm{~mm}$. Hg. There was a bilateral internal strabismus and limb reflexes were increased. The optic fundi were normal and the cerebrospinal fluid was under normal pressure.

Investigations on admission were: Blood urea 235 mg./100 ml., serum potassium $6.6 \mathrm{mEq} / 1$., serum sodium $133 \mathrm{mEq} / \mathrm{l}$, , serum chloride $95 \mathrm{mEq} / \mathrm{l}$., serum bicarbonate $24 \mathrm{mEq} / \mathrm{l}$., serum creatinine $15.2 \mathrm{mg}$./100 ml., serum inorganic phosphate $4.9 \mathrm{mg} . / 100 \mathrm{ml}$., serum uric acid $10.4 \mathrm{mg} . / 100 \mathrm{ml}$., and serum calcium $9.9 \mathrm{mg} . / 100 \mathrm{ml}$.

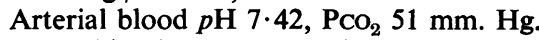

The blood pressure rose in the first 24 hours to $200 / 120$ $\mathrm{mm} . \mathrm{Hg}$, and his conscious level deteriorated with evidence of increasing irritability. Hexamethonium bromide, 1,000 mg., was given intravenously over a 12-hour period in an attempt to control the rising blood pressure. The blood urea rose to $360 \mathrm{mg}$. $/ 100 \mathrm{ml}$. 24 hours after admission, and it was decided to dialyse him because of the rapid rise and the overhydration which was felt to be responsible for the hypertension. To remove body water, ultrafiltration was employed and there was a $5 \mathrm{lb}$. $(2 \cdot 267 \mathrm{~kg}$.) weight loss during the six-hour dialysis during which the blood urea fell to $95 \mathrm{mg} . / 100 \mathrm{ml}$. (Fig. 4). His blood pressure fell to $120 / 90 \mathrm{~mm}$. $\mathrm{Hg}$ eight hours after dialysis and his conscious level became lighter. This improvement was attributed to a reduction of cerebral oedema consequent upon ultrafiltration rather than to a control of the uraemia. The blood urea had in fact risen again to $400 \mathrm{mg}$. $/ 100 \mathrm{ml}$. at the time of maximal improvement of conscious level. The oliguric period was complicated by rupture of the oesophagus on the seventh day after violent vomiting, with a rightsided pneumothorax and surgical emphysema of the chest wall and neck. A tracheostomy was performed to combat respiratory distress and to facilitate bronchial drainage following the development of a severe bilateral pneumonia. A penicillin-resistant staphylococcus was isolated from the sputum and blood culture. Treatment with methicillin $1 \mathrm{~g}$. four-hourly produced a dramatic clinical improvement. On the ninth day he passed a large melaena stool and subsequently had further 
gastro-intestinal haemorrhage. Severe muscle wasting was noticed after the fifth day with obvious fasciculation of the quadriceps. Electromyographic studies suggested a polyneuritis. The rapid muscle breakdown undoubtedly contributed to the rapidly rising blood urea and serum potassium which necessitated five six-hour haemodialyses in a period of nine days. Over this period, in spite of an adequate calorie intake (Shaldon, 1962), the patient lost $21 \mathrm{lb} .(9.5 \mathrm{~kg}$.) in weight.

He entered the diuretic phase on the fourteenth day of renal failure and subsequently made an uneventful recovery. His mental state improved and psychometric assessment six weeks after the poisoning showed only mild intellectual impairment. There was no other evidence of organic brain damage. Renal biopsy performed on the 32nd day showed dilated tubules containing birefringent calcium oxalate crystals with tubular necrosis and regeneration (Fig. 5). The patient left hospital on the 63rd day, and renal function studies before discharge were normal and were: para-aminohippuric acid clearance $1,200 \mathrm{ml} . / \mathrm{min} . / 1 \cdot 73 \mathrm{~m} .^{2}$, inulin clearance $120 \mathrm{ml} . / \mathrm{min} . / 1.73 \mathrm{~m}^{2}$, urinary maximal concentration 632 milliosmols $/ \mathrm{kg}$. and blood urea $20 \mathrm{mg}$./ $100 \mathrm{ml}$. Three months later he showed no evidence of any intellectual deficit or of any physical abnormality.

Comment. This patient developed acute renal failure with severe brain damage following the ingestion of ethylene glycol. His course was complicated by a perforated oesophagus and severe staphylococcal sepsis, but he made a full recovery after repeated haemodialyses to control his uraemia and overhydration.

\section{Discussion}

The management of acute renal failure in childhood is often complicated by the presence of over-

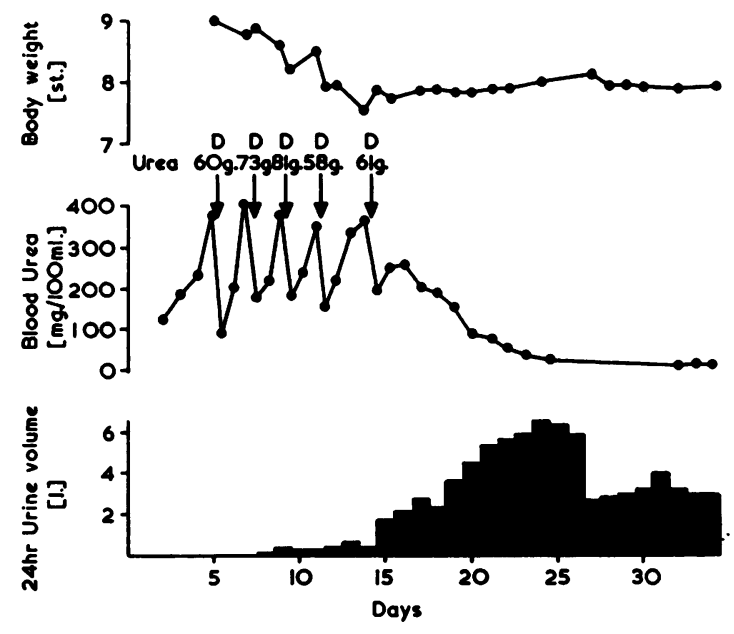

FIG. 4.-Case 3: clinical course and details of dialyses (D), with amounts of urea removed in grammes.

hydration which is much less of a problem in the adult. Thus, all three patients had hypertension, coma and cerebral irritability, and these features have been observed in other reports of children with acute renal failure (Mateer et al., 1955; Carter et al., 1957). The overhydration may be due to a failure to appreciate the proportionately reduced insensible loss and fluid requirements of the anuric child. Insensible loss in infancy is reported with wide variation depending upon the method of

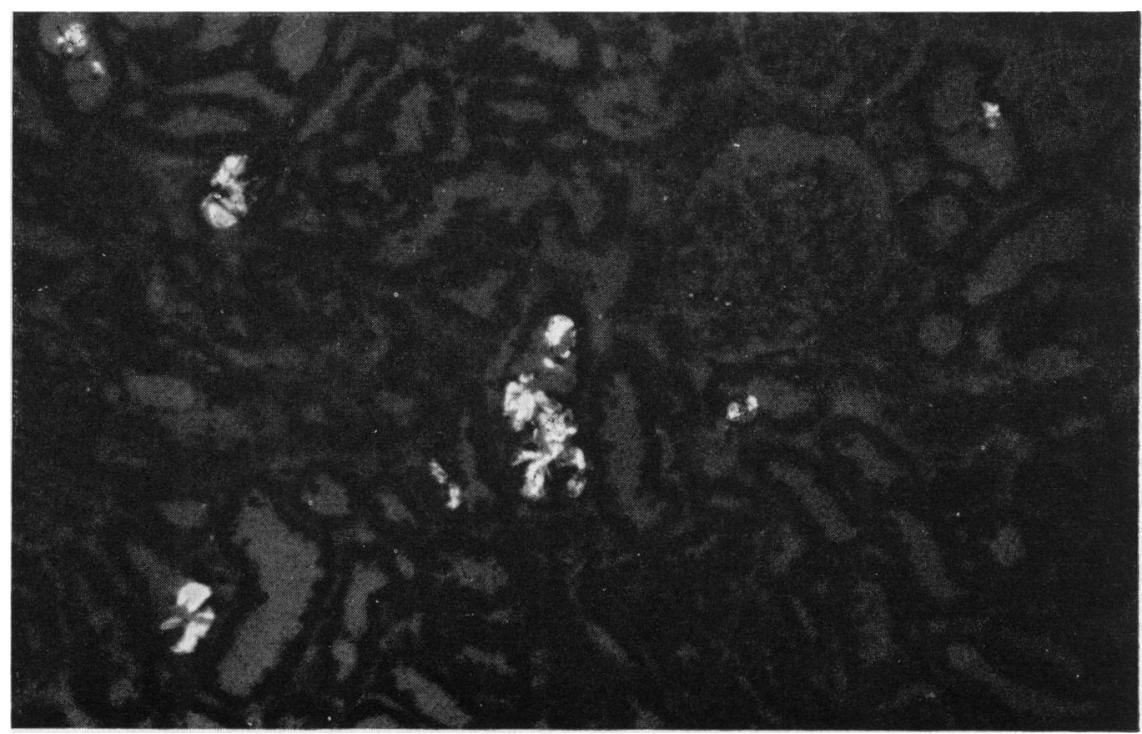

Fig. 5.-Case 3: polaroid projection of a renal biopsy performed on the 32nd day of renal failure, showing birefringent calcium oxalate crystals in damaged renal tubules. $(\times 140$. $)$ 
calculation, and there are no recent data available for the determination of its value in the anuric infant. In our infant $275 \mathrm{ml}$. per day was taken as the insensible loss, based on an estimation of 600 calories metabolized per 24 hours in an infant of this weight [20 lb. $(9.07 \mathrm{~kg}$.)] (Nelson, 1959). No evidence of overhydration was present after the first dialysis and the infant lost weight during the first three weeks (Fig. 2). Others have suggested that weight loss is the best guide to fluid requirements and the state of hydration (Carter et al., 1957). The dramatic improvement in conscious level and control of hypertension following haemodialysis with removal of body water by ultrafiltration clearly indicates the benefit of this therapy. Conservative measures are rarely of avail in the problem of overhydration as evidenced by the failure of 1,000 mg. of intravenous hexamethonium bromide to control the blood pressure in Case 3. The Kolff twin-coil kidney is much more suitable for ultrafiltration purposes than the rotating drum model: as much as $600 \mathrm{ml}$. of fluid may be removed in one hour using both coils with ultrafiltration (Black, 1959; Holmes and Nakamoto, 1959) and this may be increased to $1,200 \mathrm{ml}$. per hour if $10 \%$ glucose is added to the bath water (Nakamoto, 1961). With the twin-coil kidney it is possible to remove the excess fluid which must be infused if regional heparinization is used. This was necessary in all three patients, as all were bleeding from the gastrointestinal tract.

The delay of 24 hours in the maximal improvement in the conscious level of the infant (Case 1) after haemodialysis correlated with the delayed return of the C.S.F. $p \mathrm{H}$ to normal. This observation confirms previous suggestions that there is a delay in equilibration between the plasma and C.S.F. compartments for bicarbonate ions (Bradley and Semple, 1962), following rapid alterations in the plasma bicarbonate level. Similar observations have been made on the equilibration of urea between the plasma and C.S.F. compartments following haemodialysis (Kennedy, Linton and Eaton, 1962).

The use of early multiple haemodialyses in the management of acute renal failure is well established in the adult patient (Teschan, Baxter, O'Brien, Freyhof and Hall, 1960; Parsons, Hobson, Blagg and McCracken, 1961). The problem of catheterization of vessels to permit multiple haemodialyses has been solved in the adult by the use of the indwelling arteriovenous shunt (Quinton, Dillard and Scribner, 1960) or more recently by the technique of percutaneous puncture (Shaldon et al., 1961). This technique applied to infants and children has been satisfactory in our experience.
The 15-month-old infant had four such haemodialyses performed without complication. Successful haemodialysis in one younger infant of 11 months of age (Breakey et al., 1961) involved catheterization and cutting down on both the saphenous veins, and it is unlikely that multiple haemodialyses could have been performed.

The use of one coil of the Kolff twin-coil kidney for infants and children (Carter et al., 1957) has the advantage of reducing the priming volume of the kidney and so lessening the tendency to produce hypovolaemia and hypotension during dialysis. This complication is usually due to expansion of the coil with consequent draining of the patient's blood into the kidney and a reduction in the effective circulating blood volume. The infant (Case 1) was therefore dialysed on a sensitive weighing scale so that any rapid alteration in weight due to blood loss into the kidney coil could be detected and corrected by clamping the arterial outflow to the kidney while the venous return continued to transfuse blood back into the patient.

Only five survivors with proven renal cortical necrosis have been reported and all were adult females in whom the condition was precipitated by obstetrical complications (Crook, 1927; Gormsen, Iversen and Raaschou, 1955; Ober, Reid, Romney and Merrill, 1956; Boucot, Guild and Merrill, 1957; Lauler and Schreiner, 1958). However, renal cortical necrosis in dehydrated infants, diagnosed at autopsy, has been well documented (Campbell and Henderson, 1949), and was in fact regarded as the commonest cause of acute renal failure in infancy (Zuelzer, Charles, Kurnetz, Newton and Fallon, 1951). No previous survival from this condition in infancy has been reported. The diagnosis is dependent upon histological proof of necrosis of glomeruli in a patient with acute renal failure. Ancillary evidence includes calcification of the kidney occasionally seen on plain radiograph of the abdomen (Lloyd-Thomas, Balme and Key, 1962), but not present in our case, and a persistent elevation of the blood urea during recovery.

\section{Summary}

Three children with acute renal failure and severe overhydration were treated by haemodialysis using percutaneous catheterization of the femoral artery and vein with regional heparinization.

Overhydration is a serious problem in acute renal failure in infancy and childhood, and removal of body water by the artificial kidney is the most effective solution.

The delay in improvement in conscious level following haemodialysis correlates with the delayed 
equilibration between plasma and C.S.F. compartments and the return of the C.S.F. $p \mathrm{H}$ to normal.

The two survivors were a 15-month-old infant with proven renal cortical necrosis, dialysed on four occasions and a 15-year-old boy with ethylene glycol intoxication, dialysed on five occasions.

The policy of early repeated haemodialysis is now applicable to infants and children.

We wish to thank Dr. A. M. Ramsay and Dr. T. Parkinson for referring these cases for haemodialysis.

One of us (J.G.W.) was in receipt of a grant from the Medical Research Council, and another (M.G.) from the Endowment Fund of the Royal Free Hospital.

\section{REFERENCES}

Black, M. W. (1959). Clinical guides for the estimation of water and urea removal during hemodialysis with Kolff twin coil kidney. Trans. Amer. Soc. artif. intern. Org., 5, 50.

Boucot, N. G., Guild, W. R. and Merrill, J. P. (1957). Bilateral renocortical necrosis: with recovery: report of a case. New Engl. J. Med., 257, 416.

Bradley, R. D. and Semple, S. J. G. (1962). A comparison of certain acid-base characteristics of arterial blood, jugular venous blood and cerebrospinal fluid in man, and the effect on them of some acute and chronic acid-base disturbances. J. Physiol. (Lond.), 160,381 .

Breakey, B. A., Woodruff, M. W. and Reus, W. F., Jr. (1961). The adaptability of the Kolff twin coil artificial kidney for dialysis in infancy. J. I'rol. (Baltimore), 86, 304.

Campbell, A. C. P. and Henderson, J. L. (1949). Symmetrical cortical necrosis of the kidneys in infancy and childhood. Arch. Dis. Childh., 24, 269.

Carter, F. H., Jr., Aoyama, S., Mercer, R. D. and Kolff, W. J. (1957) Hemodialysis in children; report of five cases. $J$. Pediat. 51,125 .

Crook, A. (1927). Communication on necrosis of cortex of kidney after labour. Proc. roy. Soc. Med., 20, 27.
Gormsen, H., Iversen, P. and Raaschou, F. (1955). Kidney biopsy in acute anuria; with a case of acute, bilateral cortical necrosis. Amer. J. Med., 19, 209.

Holmes, J. H. and Nakamoto, S. (1959). Removal of fluid from the patient during hemodialysis. Trans. Amer. Soc. artif. intern. Org., 5, 58.

Kelemen, W. A. and Kolff, W. J. (1959). Use of artificial kidney in the very young, the very old, and the very sick. J. Amer. med. Ass., 171, 530.

Kennedy, A. C., Linton, A. L. and Eaton, J. C. (1962). Urea levels in cerebrospinal fluid after haemodialysis. Lancet, 1, 410.

Kolff, W. J. and Watschinger, B. (1956). Further development of a coil kidney; disposable artificial kidney. J. Lab. clin. Med., 47, 969.

Lauler, D. $\dot{P}$, and Schreiner, G E (1958). Bilateral renal cortical necrosis. Amer. J. Med., 24, 519.

Lloyd-Thomas, H. G., Balme, R. H and Key, J. J. (1962). Tramline calcification in renal cortical necrosis. Brit. med. J., 1, 909.

Mateer, F. M., Greenman, L. and Danowski, T. S. (1955). Hemodialysis of the uremic child. A.M.A. Amer. J. Dis. Child. 89,645 .

Nakamoto, S. (1961). Removal of edema fluid by ultrafiltration with the disposable twin-coil artificial kidney. Report of two cases. Cleveland Clin. Ouart., 28, 10

Nelson, W. E. (1959). Textbook of Pediatrics, 7th ed. Saunders, Philadelphia

Ober, W. E., Reid, D. E., Romney, S. L. 'and Merrill, J. P. (1956) Renal lesions and acute renal failure in pregnancy. Amer. $J$. Med., 21, 781 .

Parsons, F. M., Hobson, S. M., Blagg, C. R. and McCracken, B. H. (1961). Optimum time for dialysis in acute reversible renal failure. Lancet, 1, 129

Quinton, W. Lillard, D, and Scribner, B. H (1960). Cannulation of blood vessels for prolonged hemodialysis. Trans. Amer. Soc. artif. intern. Org., 6, 104.

Shaldon, S. (1962). Acute renal failure with particular reference to its treatment by haemodialysis. Roy. Free Hosp. J., 24, 18.

-, Chiandussi, L. and Higgs, B. (1961). Haemodialysis by percutaneous catheterisation of the femoral artery and vein with regional heparinisation. Lancet, $2,857$.

Teschan, P. E. Baxter, C. R. O'Brien, T. F., Freyhof, J. N. and Hall, W. H. (1960) Prophylactic hemodialysis in the treatment of acute renal failure. Ann. intern. Med., 53, 992.

Zuelzer, W. W., Charles, S., Kurnetz, R., Newton, W. A. and Fallon, R. (1951). Circulatory diseases of the kidneys in infancy and childhood. A.M.A. Amer. J. Dis. Child., 81, 1. 